Univerzitet u Beogradu
Poljoprivredni fakultet
Institut za poljoprivrednu tehniku
Naučni časopis
POLJOPRIVREDNA TEHNIKA
Godina XLV
Broj 4, 2020.
Strane: $71-80$

\title{
EFFECT OF MOISTURE CONTENT ON THE THERMAL PROPERTIES OF HORSE-EYE BEAN SEEDS RELEVANT TO ITS PROCESSING
}

\author{
Ide Patrick Ejike ${ }^{* 1}$, Ike Oluka², Eze Paul Chukwuka ${ }^{3}$ \\ ${ }^{1,2,3}$ Enugu State University of Science and Technology, Faculty of Engineering, \\ Agricultural and Bioresource Engineering Deparment, Enugu, Nigeria.
}

\begin{abstract}
The specific heat, thermal conductivity and thermal diffusivity of the Horse-Eye bean (Mucuna sloanei) were determined as a function of moisture content using the method reported by A.O.A.C (2000). The sample varieties used were the Big Sized and the Small Sized Horse-Eye bean. The specific heat and the thermal conductivity were measured using a Bomb Calorimeter. The thermal diffusivity was calculated from the measured specific heat, thermal conductivity and bulk density of the samples. Within the moisture range of $10.5 \%$ to $16.87 \%$ (b.b), the specific heat, thermal conductivity and thermal diffusivity varied with the moisture content. Results showed that the specific heat, thermal conductivity and thermal diffusivity of the Horse-Eye bean seeds ranged from 116.76 to $203.29 \mathrm{~kJ} / \mathrm{kgK} ; 21.07$ to $32.23 \mathrm{~W} / \mathrm{m}^{\circ} \mathrm{C}$; and $3.12 \times 10^{-7}$ to $9.19 \times 10^{-7} \mathrm{~m}^{2} / \mathrm{s}$, for the Big Sized varieties, and 112.06 to $194.61 \mathrm{~kJ} / \mathrm{kgK} ; 19.85$ to 24.08 $\mathrm{W} / \mathrm{m}^{\circ} \mathrm{C}$; and $3.05 \times 10^{-7}$ to $6.71 \times 10^{-7} \mathrm{~m}^{2} / \mathrm{s}$, for the Small Sized varieties as the moisture content increases from $10.5 \%$ to $16.87 \%$. Regression analysis were also carried out on the thermal properties of the Horse-Eye bean varieties and moisture content, and there was positive relationship between the parameters. There were significant effects of moisture content $(\mathrm{p}<0.05)$ on all the parameters conducted. The findings and the data generated will create an impact in the food processing industries for Horse-Eye bean.
\end{abstract}

Keyword: Specific heat, Thermal conductivity, Thermal diffusivity, Horse-Eye Bean flour.

*Corresponding Author. E-mail: patrick.ejike@esut.edu.ng 


\section{INTRODUCTION}

Agricultural and food material are biological and have certain unique characteristics and undergo various unit operation from pre-harvest to post harvest processing, formulation, preservation, packaging, storage distribution, domestic storage and finally consumption. During all these processes agricultural material display different behavior. Therefore, understanding the engineering properties of agricultural material at any condition are important in order to solve problems associated with designing and selecting the modes of preservation, packaging, processing, storage, marketing and consumption.

Thermal properties of agricultural materials and foods need to be known to better understand their nature and to be able to develop new technologies [16]

Thermal processes such as pasteurization, concentration, drying, heating, cooling, sterilization, thawing, cooking, refrigeration, freezing, and evaporation are frequently used in food processing, transportation, and preservation operations, [11];[9].

Knowledge of thermal properties of foods is thus crucial not only for equipment design but also for the prediction and control of various changes occurring in foods during heat transfer processes associated with storage and processing, [8] .

Thermal properties data are required both for existing foods and for new products and processes. Besides processing and preservation, thermal properties also affect sensory quality of foods as well as energy savings from processing [8]. Horse-Eye bean (mucuna sloanei), is one of the over numerous species of shrubs and climbing vines that is generally accepted due to its important benefits to humans and their environment. It is a legume mainly found in the tropical and sub-tropical part of the world, but mainly in Nigeria. In Nigeria, it is called 'ukpo' by the Igbos, 'karasuu' by the Hausas, 'yerepe' by the Yorubas, and 'ibabat' by the Efiks, [6]. It is mainly used as a food thickener in Nigeria, [11]. It contains phosphorus, but very little in the supply of iron and calcium [14]. Horse-Eye bean (mucuna sloanei), according to previous researches carried out on its nutritional content, it is known to contain $20-25 \%$ of crude protein, $43.5-49.0 \%$ carbohydrate, $25.0-27.4 \%$ of crude fiber, $5.05-7.0 \%$ fat, and $6.46-14.0 \%$ of moisture content, [2]. It contains LDOPA (a chemical that is made and used as part of the normal biology of humans and some animals and plants) a neuro transmitter that is used to treat Parkinson disease [12]. Due to its gelatization properties and gummy texture, mucuna sloanei is used as soup recipes in eating garri, pounded yam and fufu [13]. Its commercial, nutritive, medicinal and pharmaceutical values can never be over emphasized. In order to explore all these benefits of this agricultural product, (Horse-Eye bean), there is need to process it into different food formulations and food products. Processing of Horse-Eye bean involves different thermal treatment. The seed kernel will then be parboiled, dried, grounded into fine powder and packaged in fanciful bags for marketing or use for food recipes mainly for soup thickening. The existing method of carrying out this above processing procedures are task demanding, labour intensive, time consuming and very wasteful. Therefore, it is very necessary to properly understand the some of the thermal properties of this Horse-Eye bean that are relevant in the designing and fabrication of its postharvest processing machines and equipment. 
Thus, the objective of this study was to determine the effect of moisture content on the thermal properties of Horse-Eye bean seeds that are relevant to its processing, storage and handling. The concerned properties were thermal conductivity, thermal diffusivity, and specific heat.

\section{MATERIAL AND METHODS}

\section{Sample Preparation}

The Horse-Eye bean samples used for this research work were collected from a local farm at a stable storage moisture. The variety seeds of the Horse-Eye bean collected were properly cleaned and sorted to select viable seeds. The sample varieties used for the research are described as; The Big Sized variety (Ukpo Nnukwu) and The Small Sized variety (Ukpo Ntakiri). These sample varieties were further hydrated to acquire more three different moisture content levels at which the tests were carried out. The conditioned seeds were packaged in an airtight container with proper labelling and then moved to the laboratory were thermal properties were analyzed. A total of 1000 grains were used for the experiments.

\section{Determination of the Thermal Properties of Horse-Eye Bean Seeds}

\section{Determination of the Specific Heat of Horse-Eye bean}

Association of Official Agricultural Chemists [1] approved method was used. This was done with bomb calorimeter of model XRY-1A made from Shanghai Changi, China. It involves in igniting the sample in oxygen bomb calorimeter under a high pressure of oxygen gas. The heat energy that was released was absorbed by the surrounding water and this was used to estimate the energy value of the sample.1g of the sample was pelleted and turned in the oxygen bomb calorimeter. The heat of combustion was calculated as the gross energy using the method as approved by [1];

$$
\text { Energy Content }=\frac{E \Delta T-2.3 B-V}{g}\left(\frac{K J}{K G}\right)
$$

Where; $\mathrm{E}=$ Energy equivalent of the calorimeter $=13039.308 ; \Delta \mathrm{T}=$ Temperature rise;

$B=$ Length of burnt wire; $V=$ Titration volume; $G=$ Weight of the sample.

\section{Determination of the Thermal Conductivity of Horse-Eye bean}

The thermal conductivities of the Horse-Eye bean sample varieties were carried out using the line heat source probe approach method on non-stable state heat conduction. This approach is accessible, speedy and appropriate for small product samples. For sample food and agricultural materials, this approach has regularly been utilized in current times for the measurement of thermal conductivity [10]; [4].

The equipment comprises of an ammeter and voltmeter for the documentation of current and voltage correspondingly. A direct current (DC) power source was applied to supply the heat source. 
Current and voltage of $0.7 \mathrm{~A}$ and $4.5 \pm 0.5 \mathrm{~V}$ correspondingly were applied all through the experimentation. In the system, was a regulator to alter challenge in the circuit in adequate to accomplish the anticipated current for the experimentation. The prepared samples of certain moisture content were permitted to heat up to room temperature. After weighing the sample, it was placed inside the product sample hold container of $2 \mathrm{~cm}$ diameter, $7 \pm 0.5 \mathrm{~cm}$ length and $0.2 \mathrm{~cm}$ thickness. A heating coil was positioned in the center of the sample and joined outwardly to the power supply. The temperature gauge was implanted inside the product sample hold container and then the switch turned on. Taking of the temperature was carried out immediately after the product sample and sample hold cannister had attained a temperature of $30^{\circ} \mathrm{C}$. The current and voltage evaluations were regulated to $0.7 \mathrm{~A}$ and $4.5 \pm 0.5 \mathrm{~V}$, correspondingly and utilized as heat source for the product sample. Temperatures were documented at consistent periods of 30seconds for 40minutes for each product sample. The experimentation was repeated four times on each moisture content level and documented accordingly. A graph of temperature variance at the intervals took into consideration $\mathrm{T}_{2^{-}}$ $\mathrm{T}_{1}$ and this resulted to the graph plotting of the average logarithms of the conforming phase ratio $\left(\ln \frac{\theta_{2}}{\theta_{1}}\right)$. Thus, the graph slope, $\mathrm{S}$, was calculated from the straight-line segment of the graph which is given as reported by [15];

$$
S=\frac{Q}{4 \pi \Delta T}
$$

Hence, thermal conductivity is determined as,

$$
K=\frac{Q}{4 \pi \Delta T}
$$

Where; $\mathrm{K}=$ Thermal conductivity $\left(\mathrm{W} / \mathrm{m}^{\circ} \mathrm{C}\right) ; \mathrm{Q}=$ Power rating of the calorimeter $(\mathrm{J})$; $T=$ Change in temperature $(\mathrm{k})$.

\section{Measurement of the Thermal Diffusivities of Horse-Eye bean.}

The thermal diffusivities $(\alpha)$ of the Horse-Eye bean were calculated from the experimentally calculated results of the specific heat, $C_{p}$, the thermal conductivity, k, and the bulk densities, $\rho b$, of the NERICA sample varieties using the equation as reported by [4]:

$$
\alpha=\frac{K}{\rho_{b} C_{P b}}
$$

Where $\alpha$ is the thermal diffusivity $\left(\mathrm{m}^{2} \mathrm{~s}^{-1}\right), \mathrm{k}$ is the thermal conductivity $\left(\mathrm{W} \mathrm{m}^{-1}{ }^{\circ} \mathrm{C}\right.$ $\left.{ }^{1}\right), \mathrm{C}_{\mathrm{p}}$ is the specific heat $\left(\mathrm{Jkg}^{-1}{ }^{\circ} \mathrm{C}^{1}\right)$, and $\rho$ is the bulk density $\left(\mathrm{kg} \mathrm{m}^{-3}\right)$.

\section{Data Analysis}

All the thermal properties parameters were determined at three different moisture content level, and the mean values calculated for three replications at each moisture content level. 
Data were analyzed using the Statistical Analysis, Least Significant Difference (LSD) among means and was calculated at 5\% significant level $(p<0.05)$ interval.

\section{RESULTS AND DISCUSSION}

Table 1. Thermal Properties of Horse-Eye Bean varieties at different moisture content and at the temperature range of 50 to $547^{\circ} \mathrm{C}$

\begin{tabular}{|c|c|c|c|c|}
\hline $\begin{array}{c}\text { Moisture } \\
\text { Content } \\
(\%)\end{array}$ & $\begin{array}{l}\text { Sample } \\
\text { Variety }\end{array}$ & Specific Heat $(\mathrm{kJ} / \mathrm{kgK})$ & $\begin{array}{l}\text { Thermal Conductive } \\
\qquad\left(\mathrm{W} / \mathrm{m}^{\circ} \mathrm{C}\right)\end{array}$ & $\begin{array}{l}\text { Thermal Diffusivity } \\
\qquad\left(\times 10^{-7} \mathrm{~m}^{2} / \mathrm{s}\right)\end{array}$ \\
\hline \multirow[t]{2}{*}{10.5} & $\begin{array}{l}\text { Big Sized } \\
(\text { Nnukwu) }\end{array}$ & $116.76(0.02)$ & $21.07(0.66)$ & $3.21(0.68)$ \\
\hline & $\begin{array}{c}\text { Small Sized } \\
\text { (Ntakiri) }\end{array}$ & $112.06(1.01)$ & $19.85(2.08)$ & $3.05(0.04)$ \\
\hline \multirow[t]{2}{*}{13.2} & $\begin{array}{l}\text { Big Sized } \\
(\text { Nnukwu) } \\
\text { Small Size }\end{array}$ & $130.90(1.00)$ & $26.03(5.16)$ & $5.34(0.02)$ \\
\hline & (Ntakiri) & $128.22(1.99)$ & $22.89(0.03)$ & $4.68(0.02)$ \\
\hline \multirow[t]{2}{*}{16.87} & $\begin{array}{c}\text { Big Sized } \\
(\text { Nnukwu) } \\
\text { Small Sized }\end{array}$ & $203.29(0.99)$ & $32.23(0.11)$ & $9.19(0.01)$ \\
\hline & (Ntakiri) & $194.61(1.01)$ & $24.08(0.99)$ & $6.71(0.53)$ \\
\hline
\end{tabular}

N.B: Numbers in Parenthesis represents the standard deviation.

Table 2: Relationships between the Thermal Properties of Horse-Eye Bean samples with moisture content and temperature.

\begin{tabular}{|c|c|c|}
\hline \multirow{2}{*}{ Variety } & \multicolumn{2}{|c|}{ Equations } \\
\cline { 2 - 3 } & Big Sized (Ukpo Nnukwu) & Small Sized (Ukpo Ntakiri) \\
\hline Specific heat & $c=13.088 M C+28.44 T, R^{2}=0.9879$ & $c=13.088 M C+28.44 T, R^{2}=0.9879$ \\
\cline { 1 - 1 } $\begin{array}{c}\text { Thermal } \\
\text { Conductivity }\end{array}$ & $k=2.0305 M C+2.4961 T, R^{2}=0.9716$ & $k=0.6458 M C+13.537 T, R^{2}=0.8914$ \\
\cline { 1 - 1 } $\begin{array}{c}\text { Thermal } \\
\text { Diffusivity }\end{array}$ & $\alpha=0.8712 \times 10-7 M C+5.702 T, R^{2}=0.98$ & $\alpha=0.6241 \times 10-7 M C+3.5228 T, R^{2}=0.9998$ \\
\hline
\end{tabular}

Note: $\boldsymbol{c}=$ specific heat $\mathrm{kJ} / \mathrm{kg}^{\circ} \mathrm{C} ; \boldsymbol{k}=$ thermal conductivity $\left(\mathrm{W} / \mathrm{m}^{\circ} \mathrm{C}\right)$,

$\boldsymbol{\alpha}=$ Thermal Diffusivity $\left(\times 10^{-7} \mathrm{~m}^{2} / \mathrm{s}\right) ; \mathbf{M C}=$ moisture content, $\% ; \boldsymbol{T}=$ temperature, ${ }^{\circ} \mathrm{C}$.

\section{The Specific Heat}

The specific heat of the flour sample presented in Table 1 and Figure 1, showed that the specific heat of Big and Small sized Horse-Eye Bean seeds increased from 166.75 to $203.29 \mathrm{~kJ} / \mathrm{kgK}$ and 112.06 to $194.61 \mathrm{~kJ} / \mathrm{kgK}$ with increase in moisture content from $10.5 \%$ to $16.87 \%$ (d.b) for both samples respectively. The observed increase in moisture content of the sample had significant effect on the specific heat values $(\mathrm{p}<0.05)$ and this is similar with [8], who reported on the effect of moisture content on thermal properties of cowpea seeds and flours. 
The relationship between the specific heat of the seed samples as it effected by the moisture content and temperature was expressed through the linear regression equation in Table 2 as $\mathbf{c}=13.088 \mathbf{M C}+28.44 \mathbf{T}, \mathbf{R}^{2}=0.9879$ and $\mathbf{c}=13.088 \mathbf{M C}+28.44 \mathbf{T}, \mathbf{R}^{2}=$ 0.9879 for Big and Small sized Horse-Eye Bean respectively.

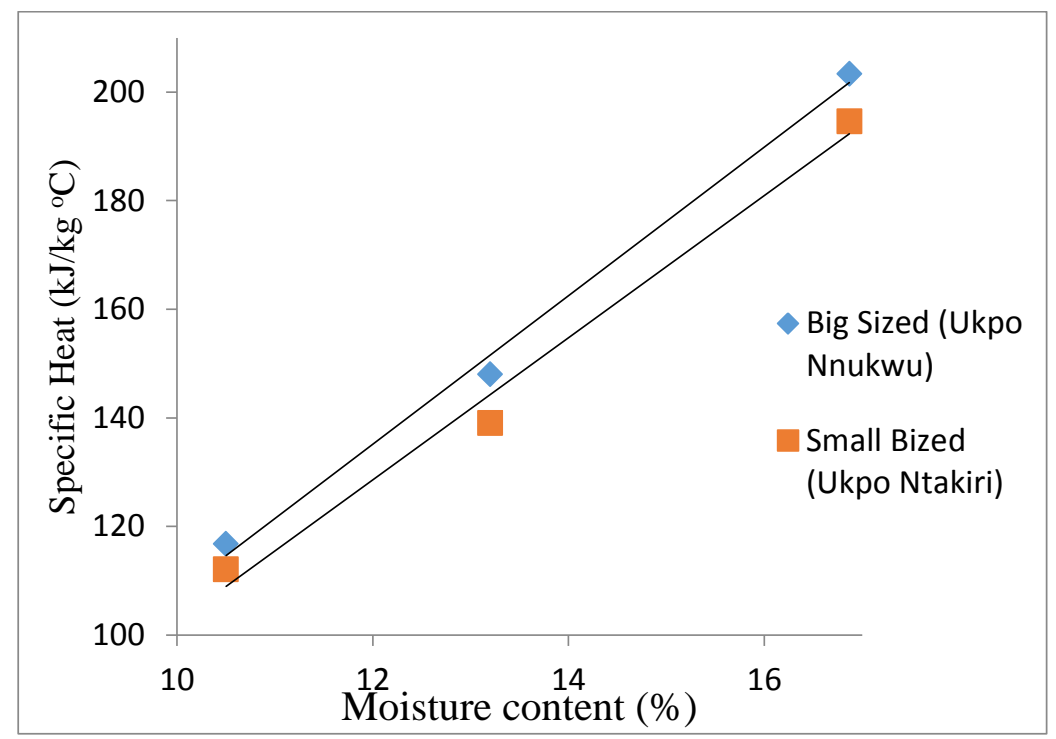

Figure 1. Effect of moisture content on the specific heat of Horse-Eye Bean seed.

\section{The Thermal Conductivity}

The thermal conductivity of both sample varieties varied with an increase in moisture content. As the moisture content increased from 10.5 to $16.87 \%$ (d.b), the thermal conductivity of the Big and Small sized Horse-Eye Bean seeds increased from 21.07 to $32.23 \mathrm{~W} / \mathrm{m}^{\circ} \mathrm{C}$ and 19.85 to $24.08 \mathrm{~W} / \mathrm{m}^{\circ} \mathrm{C}$ respectively (Figure 2) and this is in line with what [3] reported on moisture dependent of thermal properties of sheanut kernel. It was observed that, the mean value of the thermal conductivity measured at the three moisture content levels were significantly different at $(\mathrm{p}<0.05)$.

The relationship between the thermal conductivity of the Horse-Eye Bean seeds with moisture content and their temperatures, was expressed through the linear regression equation as $\boldsymbol{k}=2.0305 \mathbf{M C}+2.4961 \mathbf{T}, \mathbf{R}^{2}=0.9716$ and

$\boldsymbol{k}=0.6458 \mathbf{M C}+13.537 \mathbf{T}, \mathbf{R}^{\mathbf{2}}=0.8914$ for both Big and Small sized Horse-Eye Bean seed samples respectively. 


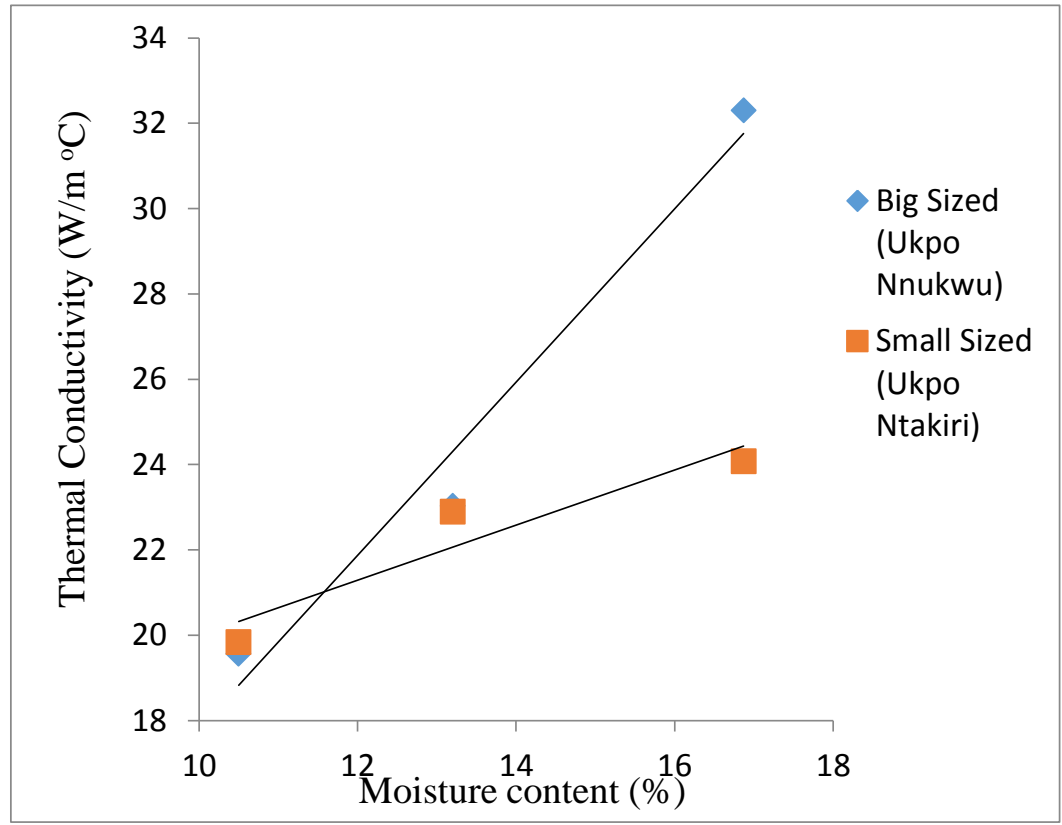

Figure 2. Effect of moisture content on the thermal conductivity of the Horse-Eye Bean seeds.

\section{The Thermal Diffusivity}

The thermal diffusivity of the Horse-Eye Bean seeds was observed to vary with change in moisture content and temperature of the sample (Table 1 and Figure 3). As the moisture content for the seed samples increased from $10.5 \%$ to $16.87 \%$ (d.b), the thermal diffusivity also increased from $3.21 \times 10^{-7}$ to $9.19 \times 10^{-7} \mathrm{~m}^{2} / \mathrm{s}$ and $3.05 \times 10^{-7}$ to $6.71 \mathrm{x}$ $10^{-7} \mathrm{~m}^{2} / \mathrm{s}$ for the Big and Small sized Horse-Eye Bean seeds respectively.

The increase in the moisture content of the Horse-Eye Bean seed samples had a significant effect on the thermal diffusivity mean value at $(p<0.05)$. [5], reported that similar trend on corn and wheat, while in contrary, [7], reported that increase in moisture of rice flour and seed decreased its thermal diffusivity increased. The relationship that exist among the thermal diffusivity, moisture content and temperature was best expressed through the linear regression equation as $\boldsymbol{\alpha}=0.8712 \times 10^{-7} \mathbf{M C}+5.702 \mathbf{T}, \quad \mathbf{R}^{2}$ $=0.98$ and $\boldsymbol{\alpha}=0.6241 \times 10^{-7} \mathbf{M C}+3.5228 \mathbf{T}, \mathbf{R}^{2}=0.9998$ for both the Big and Small sized Horse-Eye Bean seeds respectively (Table 2). 


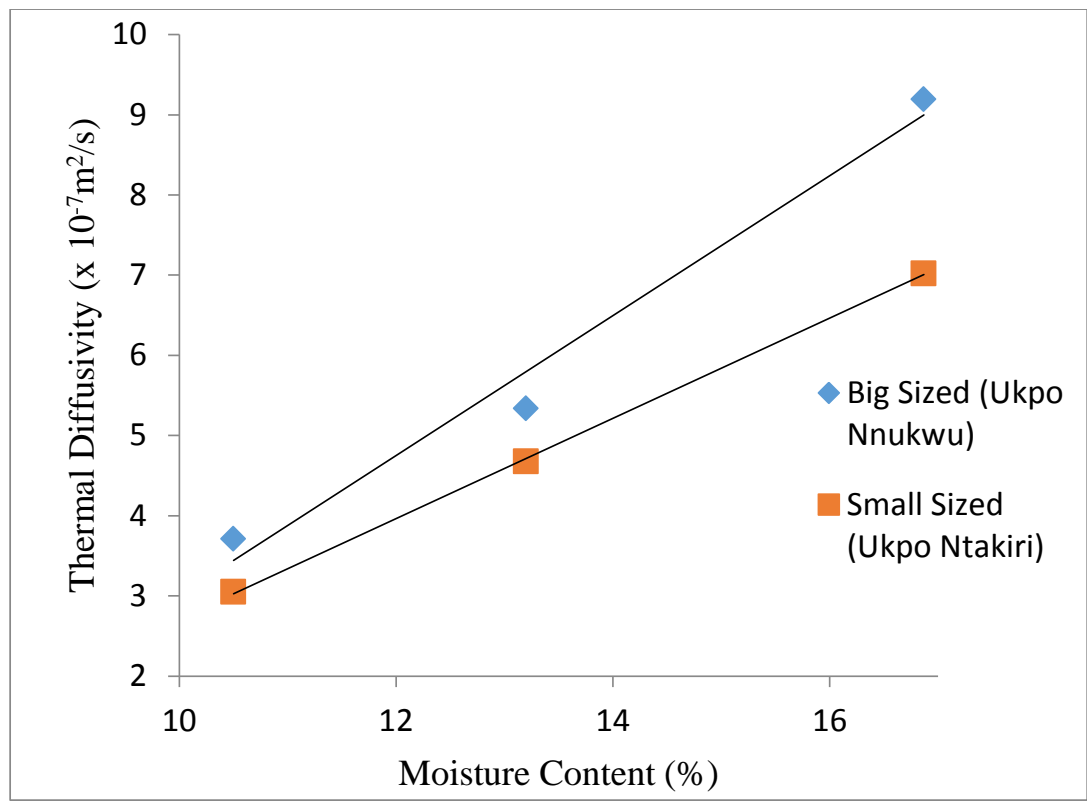

Figure 3. Effect of moisture content on thermal diffusivity of Horse-Eye Bean flour.

\section{CONCLUSION}

This study investigated thermal properties of the Horse-Eye Bean seeds as affected by moisture content and temperature and the findings revealed that;

1. The specific heat of the sample flour increased from 116.76 to $203.29 \mathrm{~kJ} / \mathrm{kgK}$ and 112.06 to $194.61 \mathrm{~kJ} / \mathrm{kgK}$ for both the Big and Small sized Horse-Eye Bean seeds respectively as the moisture content and temperature increases at the range of 10.5 to $16.87 \%$ (d.b) and 50 to $547^{\circ} \mathrm{C}$ respectively. It was observed that linear relationship exists between specific heat, moisture content and temperature.

2. Thermal conductivity of Horse-Eye Bean increased from 21.07 to $32.23 \mathrm{~W} / \mathrm{m}^{\circ} \mathrm{C}$ and 19.85 to $24.08 \mathrm{~W} / \mathrm{m}^{\circ} \mathrm{C}$ for the Big and Small size Horse-Eye Bean as moisture content and temperature ranged from 10.5 to $16.87 \%$ and 50 to $547^{\circ} \mathrm{C}$ respectively. Also, the relationship that exist between the thermal conductivity, moisture content and temperature was found to be linear.

3. Thermal diffusivity of Horse-Eye Bean increased from $3.12 \times 10^{-7}$ to $9.19 \times 10^{-7}$ $\mathrm{m}^{2} / \mathrm{s}$ and from $3.05 \times 10^{-7}$ to $6.71 \times 10^{-7} \mathrm{~m}^{2} / \mathrm{s}$ for the Big and Small sized HorseEye Bean seeds as the moisture content and temperature ranged from 10.5to $16.87 \%$ and 50 to $547^{\circ} \mathrm{C}$ respectively. It was observed that thermal diffusivity of the sample and its relationship between moisture content and temperature is be described by a linear equation. 
4. The thermal properties' results presented in this research work can find utilization in food industry in such processes where heat transport and storage properties of granular agricultural materials are very essential. They can be applied for instance for the conformation of drying rate, calibration of the economical drying time and determination of energetic balances of drying processes.

\section{REFERENCES}

[1] A.O.A.C (2000). Official Methods of Analysis 16 Ed. Association of Official Analysis Chemist. Washington DC.USA.

[2] Akpata A.O and Miachi E.U (2001) Chemical Composition and Selected Functional Properties of Sweet Orange and Legumes. Flours Plant Foods Humam Nutritions. 54:353-362.

[3] Aviara, N.A. and Haque, M.A. (2001). Moisture dependence of thermal properties of shea nut kernel. Journal of Food Engineering 47: 109-113.

[4] Bart-Plange A., Asare V. and Addo A. (2009). Thermal conductivity of maize and cowpea. Journal of Engineering and Technology, 2(3); Pp: 6-11.

[5] Božiková, Monika L. (2003). Thermophysical parameters of corn and wheat flour VL 49 10.17221/4967-RAE Research in Agricultural Engineering

[6] Eze P.C. and Eze C.N. (2017). Determination of Some Physical and Mechanical Properties of Horse Eye-Bean (Mucuna Sloanei) from South East Nigeria. Jounal of Experimental Research, June.Vol 5 No 1.

[7] Mahapatra, A. K., S. L. Melton, and E. M. Isang. (2013). Effect of moisture content on thermal properties of cowpea flours. Agric Eng Int: CIGR Journal, 15(2): 251-255.

[8] Mahapatra, A. K., Y. Lan, and D. L. Harris. (2011). Influence of moisture content and temperature on thermal conductivity and thermal diffusivity of rice flours. International Journal of Food Properties, 14 (3): 675-683.

[9] Mohen Azadbakht and Mohammad: H.K (2013). On thermal properties of Soybean pod as a function of moisture content and Temperature.AJFST.Vol.1, NO.1, No2,9-13.

[10] Mortaza, A., Mohammad, H.K. and Seyed, R.H. (2008). Specific heat and thermal conductivity of berberis fruit (Berberis vulgaris). American Journal of Agricultural and Biological Sciences, 3(1); Pp: 330-336.

[11] Nkpa U. I, (2004). The effect of length of freezing On the Thickness Property of (Mucuna sloanei) Ukpo. B.Sc Tech. Thesis, Federal University of Technology Owerri, Imo State.

[12] Nwosu, J.N, C. C, Owuamanam C.I and Onvegbu N. (2011) The Effect of Storage Condition on The Proximate and Rheological Properties of Soup Thickeners (Bruchystegia Eurycoma). Achi Report and Opinion 3: (5) 52-58.

[13] Nwosu, Justina. (2011). The Effect of Storage Condition on the Rheological/Functional Properties of Soup Thickener Mucuna Sloanei (Ukpo). Researcher. 3(6):27-32]. (ISSN: 1553-9865). http://www.sciencepub.net.

[14] Okaka, J.C., N.T. Enoch and A.NC. Okaka, (2006). Food and Human Nutrition. OCJ Academic Public, Enugu Nigeria.

[15] Sahin, S. and Sumnu, S.G. (2006). Physical properties of foods. Springer Science Business Media, LLC., 233 Spring Street, New York, NY 10013, USA.

[16] Seyed Mohammad, Taghi Gharibzahedi, Mohammad Ghahderijani and Zhaleh Sadat Lajevardi (2013). Specific Heat, Thermal Conductivity and Thermal Diffusivity of Red Lentil Seed as a Function of Moisture Content First published: 20 September. 


\title{
UTICAJ SADRŽAJA VLAGE NA TERMIČKE PARAMETRE ZRNA KONJSKOG OKA RELEVANTNOG ZA PROCES PRERADE
}

\author{
Ide Patrick Ejike ${ }^{1}$, Ike Oluka², Eze Paul Chukwuka ${ }^{3}$ \\ ${ }^{1,2,3}$ Enugu State University of Science and Technology, Faculty of Engineering, \\ Agricultural and Bioresource Engineering Deparment, Enugu, Nigeria.
}

Sažetak: Specifična toplota, toplotna provodljivost i toplotna difuzivnost zrna Konjskog oka (Mucuna sloanei) utvrđene su u funkciji sadržaja vlage metodom koju je prikazao A.O.A.C (2000). Uzorci koji su korišćeni bili su zrna od kulture velikog i malog Konjskog oka (Mucuna sloanei). Specifična toplota i toplotna provodljivost izmereni su Bomb kalorimetrom. Termička difuzivnost izračunata je iz izmerene specifične toplote, toplotne provodljivosti i zapreminske težine uzoraka. Unutar intervala sadržaja vlage od $10,5 \%$ do $16,87 \%$, variraju vrednosti: specifične toplote, toplotne provodljivosti i toplotne difuzivnosti u zavisnosti od sadržaja vlage. Rezultati su pokazali da se navedeni parametri zrna Konjskog oka (Mucuna sloanei) kreću u rasponu od 116.76 do $203.29 \mathrm{~kJ} / \mathrm{kgK} ; 21.07$ do $32.23 \mathrm{~W} / \mathrm{m}^{\circ} \mathrm{C}$; i $3.12 \times 10^{-7}$ do $9.19 \times 10^{-7} \mathrm{~m}^{2} / \mathrm{s}$, za Big sized varijetet $\mathrm{i}$ vrednost od 112.06 do $194.61 \mathrm{~kJ} / \mathrm{kgK} ; 19.85$ do $24.08 \mathrm{~W} / \mathrm{m}^{\circ} \mathrm{C}$; i $3.05 \times 10^{-7}$ do $6.71 \times 10^{-7} \mathrm{~m}^{2} / \mathrm{s}$, za varijetet Small sized, jer se sadržaj vlage povećava sa $10,5 \%$ na vrednost $16,87 \%$.

Regresiona analiza je takođe urađena sa faktorima termičkih osobina sorti zrna Konjskog oka (Mucuna sloanei) i sadržaja vlage, i između analiziranih parametara je postojala pozitivna veza. Ostvareni su značajni efekti sadržaja vlage $(\mathrm{p}<0,05)$ na sve istražene parametre. Nalazi i dobijeni podaci stvoriće pozitivan uticaj zrna Konjskog oka (Mucuna sloanei) u prehrambenoj industriji .

Ključne reči: Specifična toplota, toplotna provodljivost, toplotna difuznost, brašno od zrna Konjskog oka
Prijavljen:
Submitted:
17.03.2020.
Ispravljen:
Revised:
15.10.2020.
Prihvaćen:
Accepted:
26.10.2020. 